\title{
Modification and Optimization of Low-cost Medium for Recombinant Alkalothermophilic Xylanase Production from Pichia pastoris KM71
}

\author{
R D Cahyati ${ }^{1}$, S Hudiyono ${ }^{1}$ and I Helianti2,** \\ ${ }^{I}$ Department of Chemistry, University of Indonesia, Kampus UI, Pondok Cina, Beji, Pondok Cina, Kecamatan Beji, \\ Kota Depok, Jawa Barat 16424, Indonesia \\ ${ }^{2}$ Center for Bioindustrial Technology, Agency for The Assessment and Application of Technology (BPPT), 614 \\ Building, LAPTIAB-BPPT, Puspiptek-Serpong, Tangerang Selatan 15314, Banten, Indonesia \\ ${ }^{*}$ Corresponding author. Email: is.helianti@bppt.go.id
}

\begin{abstract}
Xylanase is an enzyme that can degrade xylan into xylooligosaccharides by cleaving to 1 , 4- $\beta$-D-xylosidic bonds and has high potential in industrial applications. In the previous study, recombinant Pichia pastoris via pPICZ-alpha vector has been constructed, and the yeast produced xylanase originally came from Bacillus halodurans CM1. Recombinant xylanase production from Pichia pastoris using standard medium has been conducted. However, if a larger scale has to be done using this standard medium, it will not be feasible, due to the high cost of the standard medium. Therefore, in this study, the composition of standard media was substituted with a low-cost substrate. Modification of production medium was conducted by replacing pure glycerol with technical glycerol as carbon source, while peptone and yeast extract as organic nitrogen source were substituted with soybean hydrolysate (18\% $(\mathrm{w} / \mathrm{v})$ total $\mathrm{N}$ content) and rice bran $(14.63 \%(\mathrm{w} / \mathrm{v})$ total $\mathrm{N}$ content), respectively, and ammonium sulphate as an additional source of inorganic nitrogen. Use of technical glycerol $1 \%(\mathrm{v} / \mathrm{v})$ and a mixture of $15 \mathrm{~g} / 100 \mathrm{~mL}$ soybean hydrolysate, rice bran hydrolysate $30 \mathrm{~g} / 100 \mathrm{~mL}$, and $2.5 \%(\mathrm{w} / \mathrm{v})$ ammonium sulphate were found to be the most suitable medium that gave high volumetric activity $(1383.9 \mathrm{U} / \mathrm{mL})$, specific activity $(861.7 \mathrm{U} / \mathrm{mg})$, protein concentration $(1.606 \mathrm{mg} / \mathrm{mL})$, and dry cell weight $(43.3 \mathrm{~g} / \mathrm{L})$.
\end{abstract}

Keywords: Xylanase, Pichia pastoris, Recombinant.

\section{INTRODUCTION}

Xylanase is the most important enzyme in the hydrolysis process of polysaccharide xylan [1], which is one of the main components of hemicelluloses and is known as the second most abundant renewable resource after cellulose [2]. Because of its remarkable ability to hydrolyze xylan and its extensive use, the industrial demand for xylanase is increasing [3]. Therefore, industrial-scale of xylanase production is required to meet the demands of the industrial market.

Center for Bioindustry Technology, Agency for The Assessment and Application of Technology (BPPT), has succeeded in isolating Bacillus halodurans CM1 strain and producing alkalothermophilic xylanase from it [4,
5]. They also succeeded in the cloning of alkalothermophilic endoxylanase gene and carrying out the production of the recombinant xylanase using Pichia pastoris KM71 yeast as an expression cell. However, the composition of the media used in this experiment is costly [6].

The cost of cultivation media in the production of recombinant proteins from $P$. pastoris is the main factor that needs to be considered and optimized for largerscale production [7]. Hence, it is interesting to formulate a suitable culture medium using low-cost raw materials. Our previous study has reported the development of an inoculum to increase enzyme production in $P$. pastoris KM71 using basal salts medium (BSM) medium as a culture medium (unpublished data). The results showed 
that recombinant enzymes produced in flask shaken at $30^{\circ} \mathrm{C}$ and $\mathrm{pH} 5.0$ showed relatively low activities (19 \pm $0.039 \mathrm{U} / \mathrm{mL}$ ) (unpublished data). In other reports, the medium modification showed an increase of enzyme activity from 118 to $204 \mathrm{U} / \mathrm{mL}$ at the flask scale [8]. The growth and recombinant protein production level in recombinant $P$. pastoris must depend on various conditions and composition of the culture medium [9].

At an industrial scale, the cost of enzyme production depends on the cost of growth and production medium used in the process [9]. Previous studies have reported about the fermentation using raw glycerol as substitution for pure glycerol that can be metabolized by yeast strains [10]. To minimize the medium costs, the crude glycerol has been used as a carbon source in $P$. pastoris culture medium to increase the cell concentration in the growth phase [11, 12]. Furthermore, soybean meal and rice bran have been used as organic nitrogen sources because they provide rich nutrients sources but inexpensive costs [12, 13].

This study is aimed at determining the suitability of a medium containing crude glycerol, soybean meal, rice bran, and ammonium sulphate for substituting a medium with high purity commercial glycerol, peptone, and yeast extract, respectively, for production of recombinant xylanase by Pichia pastoris.

\section{MATERIAL AND METHODS}

\subsection{Microbial strain}

The genetically engineered Pichia pastoris KM71 clone $3 \mathrm{E}$ which is transformed by the pPICZ $\alpha \mathrm{A}$ plasmid containing the Bacillus halodurans CM1 alkalothermophilic xylanase gene under methanol inducible $A O X 1$ promoter was provided by Center for Bioindustrial Technology, Agency for The Assessment and Application of Technology, LAPTIAB-BPPT, Pusiptek-Serpong, Tangerang Selatan [6]. The recombinant yeast was maintained on YPD $(2 \%(\mathrm{w} / \mathrm{v})$ peptone, $1 \%(\mathrm{w} / \mathrm{v})$ yeast extract, $10 \%(\mathrm{w} / \mathrm{v})$ glucose and zeocin) agar. The expression of the xylanase as a secretory product was controlled under the methanol inducible $A O X 1$ promoter and repressed by glycerol.

\subsection{Preparation of standard medium}

The standard medium for starter was BMGY (2\% $(\mathrm{w} / \mathrm{v})$ peptone, $1 \%(\mathrm{w} / \mathrm{v})$ yeast extract, and $1 \%(\mathrm{v} / \mathrm{v})$ glycerol). This mixture was sterilized by autoclaving at $121^{\circ} \mathrm{C}$ for 15 minutes, then cooled down and yeast nitrogen base (YNB), and $100 \mathrm{mM}$ potassium phosphate buffer $\mathrm{pH} 6$ were added. For xylanase production BMMY medium $(2 \%(\mathrm{v} / \mathrm{v})$ peptone and $1 \%(\mathrm{v} / \mathrm{v})$ yeast extract) was used, where the same procedure as BMGY was conducted. Induction to express the xylanase gene was done by replacing glycerol with $2 \%(\mathrm{v} / \mathrm{v})$ methanol.
This methanol concentration was used for induction in all experiments.

\subsection{Preparation of crude glycerol}

The crude glycerol (75\% (v/v) was sterilized first by autoclaving at $121^{\circ} \mathrm{C}$ for 15 minutes. Then the crude glycerol was added to the medium accordingly to give the desired final glycerol concentration (v/v) ignoring the impurities. The crude glycerol was adjusted to $\mathrm{pH}$ 7.0 prior to addition to the culture medium.

\subsection{Preparation of soybean meal and rice bran hydrolysates}

Soybean meal and rice bran were obtained from Sleman regency, Yogyakarta, Indonesia, and separately treated in $1 \mathrm{~N}$ sulfuric acid $\left(\mathrm{H}_{2} \mathrm{SO}_{4}\right)$ at $33 \%(\mathrm{w} / \mathrm{v})$. Each mixture was autoclaved at $121^{\circ} \mathrm{C}$ for $40 \mathrm{~min}$, cooled down. The distilled water added to the required volume as well as $10 \mathrm{~N} \mathrm{NaOH}$ to set the $\mathrm{pH}$ to 7.0. The suspension was then filtered and the filtrate stored at $4^{\circ} \mathrm{C}$ until use. The total nitrogen content was analyzed by the Kjeldahl method.

\subsection{Medium optimization}

The effect of nutrient composition, in terms of the concentration of crude glycerol, soybean meal, rice bran hydrolysates, and ammonium sulfate, on the growth and production of recombinant xylanase by P.pastoris was investigated in that order as follows.

For investigation of the best concentration of crude glycerol for the initial growth of P. Pastoris KM71 clone $3 \mathrm{E}$, the concentration was varied in BMGY medium $(1 \%(\mathrm{w} / \mathrm{v})$ yeast extract, $2 \%(\mathrm{w} / \mathrm{v})$ peptone, 100 $\mathrm{mM}$ potassium phosphate buffer $\mathrm{pH} 6.0$, and $1 \%$ glycerol (v/v)) by substitution of the pure glycerol with the crude glycerol at a final glycerol variations concentrations of $0.0,0.5,1.0,1.5,2.0$, and $2.5 \%(\mathrm{v} / \mathrm{v})$. $P$. pastoris was cultured on each of these media $(50 \mathrm{~mL})$ in a $250 \mathrm{~mL}$ baffled flask at $30^{\circ} \mathrm{C}$ with $250 \mathrm{rpm}$ agitation for 21-24 $\mathrm{h}$ until the optical density values $\left(\mathrm{OD}_{600}\right)$ reached 11-14 $\mathrm{OD} / \mathrm{mL}$, and then of the yeast dry cell weight (DCW) was measured.

For xylanase production by this recombinant $P$. pastoris, the yeast was first grown in the optimum crude glycerol concentration in BMGY medium (BMcGY), harvested by centrifugation (6000 rpm, $10 \mathrm{~min})$, washed in sterilized water and then resuspended and transferred into $100 \mathrm{~mL}$ BMMY medium (as per BMGY) for induction of the $A O X-1$ promoter. The cell suspension was then grown in $250-\mathrm{mL}$ baffled flasks at $30^{\circ} \mathrm{C}$ with shaking at $250 \mathrm{rpm}$ for $96 \mathrm{~h}$. For each selected methanol concentration, the same amount (final concentration) of fresh methanol was added to the culture each day $(0,24$, 48 and $72 \mathrm{~h}$ ). At 12, $24 \mathrm{~h}$ and then every $24 \mathrm{~h}$ thereafter a $1 \mathrm{~mL}$ aliquot of the cell suspension was removed to 
Table 1. Effect of crude glycerol concentration as a substitute for pure glycerol in BMGY media.

\begin{tabular}{ccccc}
\hline $\begin{array}{c}\text { Crude glyserol } \\
\text { concentration }(\mathrm{v} / \mathrm{v})\end{array}$ & Enzyme activity $(\mathrm{U} / \mathrm{mL})$ & $\begin{array}{c}\text { Protein content } \\
(\mathrm{mg} / \mathrm{mL})\end{array}$ & $\begin{array}{c}\text { Specific activity } \\
(\mathrm{U} / \mathrm{mg})\end{array}$ & $\begin{array}{c}\text { Dry cell weight } \\
(\mathrm{g} / \mathrm{L})\end{array}$ \\
\hline $0 \%$ & $217.727( \pm 11.404)$ & 0.837 & 260.127 & 14.600 \\
$0.5 \%$ & $1526.102( \pm 94.084)$ & 1.290 & 1183.025 & 20.400 \\
$1 \%$ & $4137.611( \pm 39.915)$ & 1.633 & 2533.748 & 37.800 \\
$1.5 \%$ & $4027.538( \pm 11.974)$ & 1.594 & 2526.687 & 28.200 \\
$2 \%$ & $3350.167( \pm 91.803)$ & 1.506 & 2224.546 & 27.600 \\
$2.5 \%$ & $3437.661( \pm 87.812)$ & 1.550 & 2217.846 & 42.200 \\
\hline
\end{tabular}

Table 2. Effect of soybean meal hydrolysate as a substitute for peptone in BMGY and BMMY media.

\begin{tabular}{ccccc}
\hline $\begin{array}{c}\text { Soybean meal hydrolysate } \\
(\mathrm{g} / 100 \mathrm{~mL})\end{array}$ & Enzyme activity $(\mathrm{U} / \mathrm{mL})$ & $\begin{array}{c}\text { Protein content } \\
(\mathrm{mg} / \mathrm{mL})\end{array}$ & $\begin{array}{c}\text { Specific activity } \\
(\mathrm{U} / \mathrm{mg})\end{array}$ & $\begin{array}{c}\text { Dry cell } \\
\text { weight }(\mathrm{g} / \mathrm{L})\end{array}$ \\
\hline 0 & $155.449( \pm 1.595)$ & 0.773 & 201.098 & 31.8 \\
10 & $2272.160( \pm 62.699)$ & 1.358 & 1673.167 & 32.4 \\
15 & $3002.577( \pm 21.945)$ & 1.537 & 1953.531 & 40.6 \\
23.2 & $2758.181( \pm 27.431)$ & 1.530 & 1802.733 & 33.2 \\
30 & $2610.768( \pm 5.486)$ & 1.442 & 1810.519 & 38.2 \\
35 & $2645.682( \pm 32.917)$ & 1.496 & 1768.504 & 40.1 \\
40 & $2560.337( \pm 10.972)$ & 1.461 & 1752.455 & 36.9 \\
\hline
\end{tabular}

ascertain the extracellular xylanase activity. After $72 \mathrm{~h}$, the fermentation was stopped, and the culture was sampled and determined for yeast DCW, protein concentration, enzyme activity, and specific activity.

The substitution effect of peptone with soybean meal hydrolysate (at $0,10,15,23,30,35$ and $40(\mathrm{w} / \mathrm{v}))$ on $P$. pastoris growth in the BMcGY medium with optimal glycerol concentration, and on the growth of cells and xylanase production level in BMMY medium was then evaluated as mentioned above. As organic nitrogen source, the replacement of both peptone and yeast extract in the BMGY and BMMY media with a combination of soybean meal and rice bran hydrolysates were then evaluated, but using the optimal soybean hydrolysate level and varying the rice bran hydrolysate at $0,10,15,20,25,30,35$, and $40(\mathrm{w} / \mathrm{v})$ in place of the yeast extract. Finally, the optimal modified BMcGY and BMMY media were supplemented with ammonium sulphate at $0,0.1,0.5,1.0,1.5,2.0,2.5$ and $3.0 \%(\mathrm{w} / \mathrm{v})$ as an inorganic nitrogen source for the recombinant $P$. pastoris growth and xylanase production.

\subsection{Enzyme assay}

The evaluation of the extracellular xylanase activity in the culture supernatant assay was performed by monitoring the hydrolysis of xylan as the total reducing sugar, evaluated using the dinitrosalicylic acid (DNS) method [14]. Each reaction contained $450 \mu \mathrm{L}$ of $2 \%$ $(\mathrm{w} / \mathrm{v})$ oat spelt xylan in $0.05 \mathrm{M}$ Tris- $\mathrm{HCl}$ buffer $(\mathrm{pH}$ 9.0) and $50 \mu \mathrm{L}$ of the diluted test enzyme solution. The reaction was incubated at $60^{\circ} \mathrm{C}$ for $5 \mathrm{~min}$ and then 750 $\mu \mathrm{L}$ of DNS reagent was added, incubated in a boiling water bath for $5 \mathrm{~min}$, and then cooled. Thereafter, the absorbance was measured at $540 \mathrm{~nm}$ to estimate the quantity of reducing sugars produced in the assay. One unit $(\mathrm{U})$ of xylanase activity was defined as the amount of enzyme that released $1 \mu \mathrm{mol}$ of xylose (as reducing sugar) per minute under the above assay conditions [15] Xylose (0-2 mg/mL) was used as calibration curve.

\subsection{Measurement of protein concentration}

The protein concentration was determined by the Bradford method (1976) [16]. A total of $20 \mu \mathrm{L}$ of the crude enzyme was reacted with $1 \mathrm{~mL}$ of a solution of

Bradford reagent. The mixture was homogenized with vortex and incubated at room temperature for 15 minutes and measuring the absorbance at $595 \mathrm{~nm}$. Bovine serum albumin $(0-1 \mathrm{mg} / \mathrm{mL})$ was used as a standard.

\subsection{Determination of yeast cell concentration}

The yeast DCW was determined by centrifugation (6000 rpm for $5 \mathrm{~min}$ ) of $5 \mathrm{~mL}$ of the culture broth, washing the cells with distilled water, and then drying at $105^{\circ} \mathrm{C}$ for $24 \mathrm{~h}$. DCW was then calculated from the obtained mass $(\mathrm{g} / \mathrm{L})$. Moreover, the concentration of the cell yeast was estimated in terms of the optical density (OD) of the suspension at $600 \mathrm{~nm}\left(\mathrm{OD}_{600}\right)$.

\section{RESULT AND DISCUSSION}

In this study, an attempt to reduce the cost of cultivation media was evaluated to obtain efficient 
Table 3. Effect of rice bran hydrolysate as substituted for yeast extract in BMGY and BMMY media

\begin{tabular}{ccccc}
\hline $\begin{array}{c}\text { Rice bran hydrolysate } \\
(\mathrm{g} / 100 \mathrm{~mL})\end{array}$ & Enzyme activity $(\mathrm{U} / \mathrm{mL})$ & $\begin{array}{c}\text { Protein content } \\
(\mathrm{mg} / \mathrm{mL})\end{array}$ & $\begin{array}{c}\text { Specific activity } \\
(\mathrm{U} / \mathrm{mg})\end{array}$ & $\begin{array}{c}\text { Dry cell weight } \\
(\mathrm{g} / \mathrm{L})\end{array}$ \\
\hline 0 & $17.908( \pm 0.798)$ & 0.418 & 42.841 & 12.9 \\
10 & $133.638( \pm 10.902)$ & 0.508 & 263.067 & 23.2 \\
15 & $136.608( \pm 19.319)$ & 0.514 & 265.774 & 27.7 \\
20 & $242.331( \pm 17.639)$ & 0.652 & 371.673 & 30.2 \\
24,9 & $283.313( \pm 12.600)$ & 0.723 & 391.858 & 31.5 \\
30 & $700.858( \pm 12.600)$ & 1.060 & 661.187 & 38.3 \\
45 & $614.736( \pm 8.400)$ & 0.961 & 639.683 & 32.6 \\
\end{tabular}

xylanase production by Pichia pastoris. The main effect of the low-cost media (carbon and nitrogen sources) on the growth and enzyme production was observed [17].

\subsection{Cultivation of Pichia pastoris KM71 in BMGY medium utilizing crude glycerol to replace commercially pure glycerol}

Glycerol is commonly used as the main carbon source that provides energy to increase the production of Pichia pastoris' metabolite [18]. By utilizing crude glycerol in growth and production media, the highest level of enzyme activity was obtained at $1 \%(\mathrm{v} / \mathrm{v})$ glycerol concentration, and $37.8 \%$ dry cell weight (DCW), with a specific activity of $2533.748 \mathrm{U} / \mathrm{mg}$ (Table 1). The concentrations below and above $1 \%$ show that xylanase production was not optimal, as previously reported that the crude glycerol concentration above or below $1 \%(\mathrm{v} / \mathrm{v})$ resulted in lower yeast yields [12]. This happened because glycerol is needed as a carbon source in a certain amount to optimally stimulate cell growth and xylanase production. Based on Invitrogen (2010) [19], the optimal concentration of glycerol is needed at a concentration of $1 \%$. When more than $1 \%$, it will make the cells, unable to capture carbon as a source of nutrition, so it is no longer able to secrete xylanase optimally. Thus, $P$. pastoris was initially inoculated in BMGY medium with $1 \%(\mathrm{v} / \mathrm{v})$ crude glycerol replacing commercial glycerol (hereafter referred to as BMcGY). Also, the economic saving would still be obtained since, as compared to the pure glycerol (US\$155.92 per $\mathrm{kg}$ ), the crude glycerol was cheaper (US\$2 per $\mathrm{kg}$ ). In many industrial fermentations, crude glycerol has been used as the carbon source [20]. For biotechnological applications, it may make it economically feasible as a cheaper carbon source.

\subsection{Growth of recombinant Pichia pastoris KM71 and production of xylanase in BMGY and BMMY medium utilizing organic nitrogen sources}

Nitrogen sources play an important role in microorganism growth and metabolite production [18]. Based on the Kjeldahl method, the total nitrogen content of soybean meal and rice bran hydrolysates was $0.84 \%$ and $0.65 \%(\mathrm{w} / \mathrm{v})$, respectively; whereas that of peptone and yeast extracts were $18 \%$ and $14.63 \%$ (w/v), respectively.

\subsubsection{Soybean meal hydrolysate replacement for peptone.}

Soybean meal is considered to be one of the most nutritious plants because of its protein content [21]. However, macromolecular proteins need to be further degraded into small molecular peptides and even become amino acids before they are absorbed and utilized by microbes. Therefore, the hydrolysis process is needed to reach amino acids and absorbable peptides [22]. Utilizing the soybean hydrolysate as a substitute for peptone in BMcGY and BMMY medium was able to support the growth of P. pastoris [13], with an increasing yeast yield being obtained with an increasing soybean meal hydrolysate concentration up to a maximum yeast yield and xylanase production at 15 $\mathrm{g} / 100 \mathrm{~mL}$ soybean hydrolysate (Table 2). This is comparable with enzyme activity, protein content, specific activity, and dry cell weight (DCW) obtained with the peptone containing BMcGY medium. Therefore, the medium both BMcGY and BMMY were modified to contain $15 \mathrm{~g} / 100 \mathrm{~mL}$ soybean meal hydrolysate in place of peptone (hereafter, we designated as BMcGYS and BMMYS, respectively).

The modified medium containing soybean meal hydrolysate (BMcGYS) used for $\mathrm{P}$. pastoris starter cultivation, and BMMYS medium for xylanase production, after induction with methanol, could support xylanase production, with a maximum level (3002.577 $\mathrm{U} / \mathrm{mL}$ or $1953.531 \mathrm{U} / \mathrm{mg}$ ) (Tabel 2). The standard medium gave $5823.801 \mathrm{U} / \mathrm{mL}$ or $3324.42 \mathrm{U} / \mathrm{mg}$ xylanase activity. Although the activity was less than that of standard, however, they are comparable in the same digit. Therefore, soybean meal hydrolysate has the potential to replace peptone. 
Table 4. Effect of ammonium sulphate concentration in BMGY and BMMY media.

\begin{tabular}{ccccc}
\hline $\begin{array}{c}\text { Ammonium sulphate } \\
\text { concentration }(\mathrm{v} / \mathrm{v})\end{array}$ & $\begin{array}{c}\text { Enzyme activity } \\
(\mathrm{U} / \mathrm{mL})\end{array}$ & $\begin{array}{c}\text { Protein content } \\
(\mathrm{mg} / \mathrm{mL})\end{array}$ & $\begin{array}{c}\text { Specific activity } \\
(\mathrm{U} / \mathrm{mg})\end{array}$ & $\begin{array}{c}\text { Dry cell weight } \\
(\mathrm{g} / \mathrm{L})\end{array}$ \\
\hline $0.0 \%$ & $289.846( \pm 20.159)$ & 0.498 & 582.021 & 17.1 \\
$0.1 \%$ & $293.410( \pm 15.119)$ & 0.522 & 562.088 & 21.8 \\
$0.5 \%$ & $281.531( \pm 11.760)$ & 0.514 & 547.726 & 22.5 \\
$1.0 \%$ & $301.725( \pm 10.080)$ & 0.639 & 472.184 & 24.8 \\
$1.5 \%$ & $565.438( \pm 18.479)$ & 1.033 & 547.375 & 35.9 \\
$2.0 \%$ & $808.957( \pm 18.479)$ & 1.526 & 530.116 & 38.1 \\
$2.5 \%$ & $1383.898( \pm 8.400)$ & 1.606 & 861.705 & 43.3 \\
$3.0 \%$ & $939.625( \pm 5.040)$ & 1.573 & 597.346 & 43.7 \\
\hline
\end{tabular}

\subsubsection{Rice bran hydrolysate to replace yeast extract.}

The rice bran hydrolyzate used as a substitution for yeast extract in BMcGY and BMMY, and we named the medium as BMcGYSR and BMMYSR. A report described that these mediums were able to support the growth of P. pastoris [13]. In our study, the optimal concentration of rice bran hydrolysate concentration that gave maximal xylanase activity $(700.858 \mathrm{U} / \mathrm{mL})$ was at $30 \mathrm{~g} / 100 \mathrm{~mL}$ (Table 3).

Although the xylanase activity using this medium was less than that of using the standard medium, but still the possibility of financial savings was obtained. Thus, the hydrolysate mixture of soybean meal and rice bran can be used as a low-cost nitrogen source for enzyme production.

\subsection{Growth of Pichia pastoris KM71 and xylanase production in BMGY and BMMY medium using inorganic nitrogen sources}

Supplementing ammonium sulphate in the BMcGYSR and BMMYSR medium, as an inorganic nitrogen source was able to increase the enzyme activity, protein content, dry cell weight (DCW), and specific activity. The optimal ammonium sulphate concentration that gave maximal xylanase activity was $2.5 \%(w / v)$ (Table 4). The BMcGYSR and BMMYSR supplemented by ammonium sulphate were named as BMcGYSRA and BMMYSRA, respectively.

The modified BMcGYSRA and BMMYSRA media could increase yeast growth, xylanase activity, and protein content compared to media without ammonium sulfate. A study reported that ammonium salt is a good source of nitrogen for yeast growth, hence fermentation media is often equipped with inexpensive inorganic nitrogen, such as ammonium sulfate. However, to increase yeast growth, it is not enough if only ammonium salt is used, because cells need growth factors such as amino acids, vitamins, and other nutrients that have specific roles in catalytic or structural reactions [23].

\section{CONCLUSION}

A low-cost medium for recombinant xylanase production from recombinant Pichia pastoris KM71 was proposed. The $1 \%(\mathrm{v} / \mathrm{v})$ crude glycerol, $15 \mathrm{~g} / 100$ $\mathrm{mL}(\mathrm{w} / \mathrm{v})$ soybean meal, and $30 \mathrm{~g} / 100 \mathrm{~mL}(\mathrm{w} / \mathrm{v})$ rice bran hydrolysates were investigated to replace the $1 \%$ $(\mathrm{v} / \mathrm{v})$ pure glycerol, $2 \%(\mathrm{w} / \mathrm{v})$ peptone, and $1 \%(\mathrm{w} / \mathrm{v})$ yeast extract in standard BMGY and BMMY media, respectively. Supplementation of $2.5 \% \quad(\mathrm{w} / \mathrm{v})$ ammonium sulphate in this low medium increased xylanase activity. The media will provide a feasible economic advantage of recombinant enzymes by Pichia pastoris for the industrial-scale production, however, still, the further experiment related to the optimization of fermentor physical condition for production must also be conducted.

\section{ACKNOWLEDGMENTS}

This work was funded by the INSINAS Research Incentives Program of Indonesia Ministry of Research, Technology, and Higher Education in the year 20192020 granted to IH. The authors thank Lina Mulyawati and Haniyya for their technical assistance.

\section{REFERENCES}

[1] Walia A, Guleria S, Mehta P, Chauhan A and Parkash L 2017 Microbial Xylanases and Their Industrial Application in Pulp and Paper Biobleaching: A Review 3 Biotech. 7(11) 1-12

[2] Cayetano-cruz M, Pérez de los Santos A L, García-Huante Y, Hernández A S, Pavón-Orozco P, López P E and Hidalgo-Lara M E 2016 HighLevel Expression of a Recombinant Xylanase by Pichia Pastoris Cultured in a Bioreactor with Methanol as the Sole Carbon Source: Purification and Biochemical Characterization of the Enzyme Biochemical Engineering Journal. $112161-69$ 
[3] Ethiraj, Selvarajan and R Veena 2017 Recent Advances and Future Perspectives of Thermostable Xylanase Recent Advances and Future Perspectives of Thermostable Xylanase Biomedical and Pharmacology Journal 10(1) 261-79

[4] Ulfah M, Helianti I, Wahyuntari B and Nurhayati N 2011 Characterization of a new themoalkalophilic xylanase-producing bacterial strain isolated from Cimanggu Hot Spring, West Java Indonesia Microbiol Indones 5(3)

[5] Helianti I, et al. 2018. Proses produksi xilanase tahan panas dan tahan basa untuk diaplikasikan pada industri kertas (Paten granted no IDP000025610)

[6] Haniyya, Mulyawati L, Helianti I, Nimchua T, Pinmanee $\mathrm{P}$, Kocharin $\mathrm{K}$ and Canthasingh $\mathrm{D}$. Production and characterization of recombinant Bacillus halodurans CM1 xylanase from Pichia pastoris KM71 and its application in bleaching process of bagasse pulp. Submitted

[7] Yadav K, Dhiman S, Baruah I, and Singh L 2011 Development of cost-effective medium for the production of Bacillus sphaericus strain isolated from Assam, India J. Microbiol 1 p 6570

[8] Chen, Chang C, Wu P H, Huang C T and Cheng K J 2004 A Pichia Pastoris Fermentation Strategy for Enhancing the Heterologous Expression of an Escherichia Coli Phytase Enzyme and Microbial Technology 35 315-20

[9] Batista K A, Bataus L M, Campos T N, and Fernandes F K 2013 Development of culture medium using extruded bean as a nitrogen source for yeast growth J. Microbiol 92 310-315

[10] Papanikolaou S, Muniglia L, Chevalot I, Aggelis G, and Marc I 2002 Yarrowia lipolytica as a potential producer of citric acid from raw glycerol J. Appl. Microbio 92 737-744

[11] Celik E, Ozbay N, Oktar N, and Cahk P 2008 Use of biodiesel byproduct crude glycerol as the carbon source for fermentation processes by recombinant Pichia pastoris Ind. Eng. Chem. Res. 47 2985-2990

[12] Orachun S, Malilas W, Boonvitthya N, Burapatana V and Chulalaksananukul W 2014 Low Cost Medium for Recombinant Endoglucanase II Production by Pichia Pastoris African Journal of Microbiology Research 8(25) 2474-81

[13] Sereewatthanawut I, Prapintip S, Watchiraruji K, Goto M, Sasaki M and Shotipruk A 2008. Extraction of protein and amino acids from deoiled rice bran by subcritical water hydrolysis. J. Bioresour. Technol 99 p 555-561
[14] Miller G L 1959 Use of dinitrosalicylic acid reagent for determination of reducing sugar Anal. Chem 31 p 426-428

[15] Ali A A M, Al-Astal H I M, Almatar M and Hawege E F 2014 Production of Xylanase Enzyme from Aspergillus terreus SUK-1 International Journal of ChemTech Research 6(11) 974-4290

[16] Bradford M M 1976 A rapid and sensitive method for the quantitation of microgram quantities of protein utilizing the principle of protein-dye binding Anal. Biochem. 72 248-254

[17] Charoenrat T, Khumruaengsri N, Promdonkoy P, Rattanaphan N, Eurwilaichitr L, Tanapongpipat $\underline{S}$ and Roongsawang N 2013 Improvement of Recombinant Endoglucanase Produced in Pichia Pastoris KM71 through the Use of Synthetic Medium for Inoculum and $\mathrm{pH}$ Control of Proteolysis Journal of Bioscience and Bioengineerin 116(2) 193-98

[18] Shang T, Si D, Zhang D, Liu X, Zhao L, Hu C, Fu Y and Zhang R 2017 Enhancement of Thermoalkaliphilic Xylanase Production by Pichia Pastoris through Novel Fed-Batch Strategy in High Cell-Density Fermentation. BMC Biotechnology 17(55) 1-10

[19] Invitrogen $2010 \quad$ EasySelect $^{\mathrm{TM}}$ Pichia Expression Kit: For Expression of Recombinant Proteins Using pPICZ and pPICZ $\alpha$ in Pichia Pastoris. California: Invitrogen Corporation

[20] Chatzifragkou A, Makri A, Belka A, Bellou S and Mavrou M 2011 Biotechnological conversions of biodiesel derived waste glycerol by yeast and fungal species Energy 36 pp 1097 1108

[21] Yigit M, Turker A, Ergün S and Harmantepe B 2010 Evaluation Of Soybean Meal As A Protein Source And Its Effect On Growth And Nitrogen Utilization Of Black Sea Turbot (Psetta Maeotica) Juveniles Journal of Marine Science and Technology 18(5) 682-88

[22] Liu J, Zhou J, Wang L, Ma Z, Zhao G, Ge Z, Zhu H, and Qiao J 2017 Improving Nitrogen Source Utilization from Defatted Soybean Meal for Nisin Production by Enhancing Proteolytic Function of Lactococcus Lactis F44 Scientific Reports 7(6189) 1-13

[23] Yalcin, Karasu S and Ozbas Z Y 2008 Effects of Ammonium Sulphate Concentration on Growth and Glycerol Production Kinetics of Two Endogenic Wine Yeast Strains Organisms Generally Used for Glycerol Production Indian Journal of Biotechnology 7 89-93 